\title{
The Impact of Family Violence on Education and the Extent of Students' Enrollment in Public Schools in Amman in the Light of Some Variables from the Perspective of the Special Education Teachers at These Schools
}

\author{
Dr. Abdulnaser Fahkrou \\ Qatar University- Faculty of Education \\ Dr. Ibrahim Ali Al-Baher
}

\begin{abstract}
The present study aimed to explore the impact of family violence on education and the extent of students' enrollment in public schools in Amman in the light of some variables from the perspective of the special education teachers at these schools. The sample consists from 400 special education teachers. Those teachers were selected through the random cluster sampling method. A descriptive survey-based approach was adopted. To meet the study's goals, a questionnaire was developed. The validity and reliability of the questionnaire were measured. It was found that the severity of the impact of family violence on education and the extent of students' enrollment in public schools in Amman is high. It was found that there are statistically significant differences -at the statistical significance level of $(\mathrm{a} \leq 0.05)$ - between the respondents' attitudes which can be attributed to gender. The latter differences are for the favor of females. It was found that there isn't any statistically significant difference -at the statistical significance level of $(\mathrm{a} \leq 0.05)$ - between the respondents' attitudes which can be attributed to experience or academic qualification. The researchers recommend activating the role of teachers in fighting against family violence and its impacts on students' enrollment in schools. They recommend activating the role of social studies teachers in communicating with parents. They recommend conducting studies about the factors affecting the student's family environment. They recommend holding several symposiums in cooperation with the civil society institutions in order to promote awareness about the implications of family violence. Through holding such symposiums, people must be encouraged to fight against family violence. In addition, they recommend encouraging students to talk about the family violence incidents that occurred with them. That is because the being afraid of talking about such incidents shall increase them.
\end{abstract}

Keywords: family violence, education, school

DOI: $10.7176 / \mathrm{JEP} / 11-12-07$

Publication date: April $30^{\text {th }} 2020$

\section{Introduction}

Education plays a significant role in enabling any society to achieve development in various economic, social, scientific and political areas. All societies face many challenges and problems. However, if the society provides much attention to education, it shall become capable to handle all its problems and challenges. However, that requires exerting much effort and collaboration. All societies seek providing much attention to family health. That is because family is the first social body that raises up and develops the future generation. For instance, the child grows up among his/her family. He/she acquires his/her family criteria in classifying things into right and wrong. However, in case this institution turns into a place that is full of violence, it shall lead to raising people who are psychologically imbalanced.

Family violence may be practiced against the family members who are about to enroll in school. It may be practiced against the family members who have already enrolled in school. It shall lead to experiencing philological, psychological or social problems by the victims. Such problems may be experienced for a long time of their lives. They may become involuntary behaviors. They may be transmitted to the future generation. They may change their personalities. In fact, family violent behaviors may be transmitted from one generation to another. That shall keep the latter behaviors existent in society. It shall hinder students from enrolling in schools. It shall increase the number of the students who run from their schools. It shall increase the academic failure rates. It shall increase the amount of wasted resources by educational resources. Thus, family violence serves as a real threat facing the social security of people in general.

Family plays a very significant role in socialization. Children acquire their values and principles from their families. They shall keep adopting these values and principles during their whole lives. Family plays a significant role in developing children and shaping their personalities (Gazwan, 2015).

According to the experts in education, the students who are victims for family violence usually show a low academic achievement. That is because those students tend to be absent more than other students. It is because those students usually carrying out bullying behaviors against other students. That shall make students dismissed 
from school or prosecuted (Hussain, 2017).

Many studies suggest that it is very important to explore the impacts of family violence on students' enrollment in schools. That must be explored to adopt effective strategies for fighting against family violence. Such policies must detect family violent behaviors. They must provide effective solutions for preventing or reducing the occurrence of such behaviors. They must address the way of increasing the enrollment of the victimized students and teenagers in schools and colleges.

Katebi (2012) defines family violence as direct or indirect acts that are carried out against a family member to hurt him/her psychologically, verbally, physically or sexually.

Bushnaq (2014) defines family violence as any act that may cause physical, moral or financial harm to a family member.

Family violence has been receiving much attention by the educational organization. That is because family violence has several impacts on students' behaviors and the educational process. It's because family violence has several impacts on the social institutions concerned in human right issues. The latter impacts are related to the extent of meeting their intended goals. They are related to the relationships of those institutions with others. Hence, the capability of organizations to fight against family violence shall affect their capability to meet their intended goals. The latter goals are related to enabling the students who are victimized by their families to enroll in schools. They are related to enabling those students to integrate effectively in a healthy school environment that is free from conflicts and violence (Abu Gazaleh, 2008).

Several studies suggest that family violence plays a very significant role in hindering the victimized students from enrolling in schools. For instance, Gazwan (2015) suggests that the probabilities of having the victimized students hindered from enrolling in schools are high. Al-Katebi (2012) suggests that there is a strong relationship between family violence and the non-enrollment of the victimized students in schools. Hayat (2010) suggests that the students who are victimized by their families are highly willing to join schools. However, the violence they suffer from and the poor socio-economic status of their families hinder them from enrolling in schools. Due to such poor socio-economic status, those students shall be forced to leave schools. To illustrate more, those students shall become forced to work and provide their families with income rather than studying. That shall hinder the state from applying its educational policies. It shall hinder the state from providing people with educational opportunities equally. Al-Kasab (2011) suggested the same. He addressed family violence and its impacts on hindering students from enrolling in schools.

\section{Statement of the Problem:}

All educational organizations seek providing effective education that utilizes students' potential and capabilities effectively. They seek providing effective education that improves students' behaviors and expand their knowledge. They seek providing effective education that ensures a high level of interaction, integration and active collaboration. They seek providing effective education that ensures having behavioral discipline and presents absence and running from schools. They seek providing effective education that reduces the rate of academic failure and provides attention to school curricula. They seek providing education of high quality that meet the intended goals of the educational system in general. The researchers of the present study noticed that the rates of students' academic failure, running from schools and absence in Amman are high in public schools. Based on the studies of Al-Fawaz (2008), Abu Gazaleh (2008), Al-Sarayrah (2009), Al-Kassab (2011) and Al-Sa'aydeh (2014), such high rates are attributed to family violence. In the light of the aforementioned information, the present study aimed to explore the impact of family violence on education and the extent of students' enrollment in public schools in Amman in the light of some variables from the perspective of the special education teachers at these schools. To be specific, the present study aimed to answer the following questions:

Q.1. What is the severity of the impact of family violence on education and the extent of students' enrollment in public schools in Amman from the perspective of the special education teachers at these schools?

Q.2. Is there any statistically significant difference -at the statistical significance level of $(\mathrm{a} \leq 0.05)$ - between the respondents' attitudes which can be attributed to gender?

Q.3. Is there any statistically significant difference -at the statistical significance level of $(\mathrm{a} \leq 0.05)$ - between the respondents' attitudes which can be attributed to academic qualification?

Q.4. Is there any statistically significant difference -at the statistical significance level of $(\mathrm{a} \leq 0.05)$ - between the respondents' attitudes which can be attributed to experience?

\section{The Study's Significance}

All societies seek enrolling all young people in schools. They seek preventing the occurrence of violent behaviors against students. That is because such violence may hinder students from obtaining their educational degrees. The present study's significance is illustrated below:

-Theoretical significance: The present study provides researchers with a new knowledge about family violence and its impacts on education and the extent of students' enrollment in schools. 
-Practical significance: The present study is significant because it assists decisions makers and policy developers in the state in creating a stable family climate. It is significant because it promotes collaboration among all social institutions in fighting against family violence and meeting the state's goals. Such goals include goals related to developing people and shaping their personalities. They include goals related to the promotion of social and behavioral discipline.

\section{The present is significant because}

It promotes awareness among officials in various educational institutions about the significance of fighting against family violence. Family violence can be prevented through activating the role of schools and strengthening the relationship between schools and families.

It provides the researchers who want to conduct similar studies with a theoretical framework. It provides those researchers with results and recommendations. It provides them with an instrument that can be applies on other samples.

\section{Definition of the study's terms}

After reviewing the relevant literature, the researchers defined the terms listed below as follows:

-Violence: It is an illegitimate use of physical power in order to cause harm to others or their properties. It involves rape and infringing others' freedoms. It is an infringement against others' dignity and reducing the victims' selfesteem. It may involve verbal, psychological or physical abuse. It may involve murder (Bahri, 2011).

Family: It refers to a several members who live together. Among the family, the child shall be raised up. Among the family, the child shall form his/her first human relationships. The family is responsible for letting the child acquire positive behaviors. The capability of the child to adjust socially with others may be attributed to the nature of the relationships between family members (Tarbeye, 2012).

Family violence: It refers to an illegitimate use of physical power in order to cause harm by an adult family member against another family member. The victims of family violence are usually children at home (Abed Al-Jawad and Al-Batayneh, 2004).

-Education: It is an interactive process through which expertise, skills and information shall be transmitted from the teacher to the learner who wants to learn (Al-Taweeel, 2009).

-School: It is an institution that transmits cultural, ethical and social values to students. It enables students to integrate socially in their environment (Al-Baher, 2015).

\section{The Study's Limits}

The study's limits are listed below:

- Human limits: The present study sampled several special education teachers who work in public schools in Amman.

- Spatial limits: The present study was conducted in public schools in Amman.

- Temporal limits: The present study was conducted during the academic year of 2019/2020.

\section{Review of Literature}

This part includes a review for the relevant previous studies. Some of those studies were conducted in Arabic language. The other studies were conducted in English language. These studies are arranged in accordance with the year of publication (from the oldest to most recent ones).

Lambi (2008) aimed to explore the effectiveness of a school counselling program targeting the children who suffer from family violence. The sample consists from 30 children. The researcher used a check list that was filled through observation. It was found that the latter program is effective in reducing the children's behavioral problems. It was found that the physical violence is most prevalent type of family violence.

Al-Sarayrah (2009) aimed to explore the reasons leading male public secondary school students to committing violent behaviors against teachers and administrators in Jordan. He aimed to explore that from the perspective of students, teachers and administrators. The sample consists from 945 individuals; 100 administrators, 200 teachers, and 645 students. It was selected through using the random cluster sampling method. To collect data, the researcher developed a questionnaire. The questionnaire consists from 2 parts. The first part collect demographic data about the respondent. The second part collect data about the reasons leading students tocommit violent behaviors against teachers and administrators. It was found that the severity of the reasons leading students to commit violent behaviors against teachers and administrators is moderate.

Fredric \&Fredjr (2010) aimed to explore the extent of improving children protection through providing parents with a counselling program. The sample consists from 20 families who suffer from family violence. 10 families of those fall under the experimental groups. The other families fall under the control group. It was found that the latter counselling program is effective in promoting positive interaction between parents and their children. It was found that the latter counselling program is effective in reducing the emotional and behavioral problems 
that children suffer from. It was found that the latter counselling program is effective in promoting awareness among parents about the way of protecting children from emotional and behavioral problems. Such protection can be provided through promoting positive interaction between parents and their children in social, emotional, health and educational areas.

Janson \& Brown (2008) aimed to explore the extent of compliance with the laws of children protection in the family. They aimed to explore the extent of protecting children from harsh punishment, abuse and poor work conditions. The sample consists from 6 groups that involve 60 children. It also consists from 8 groups involving 44 parents. The members of the sample vary in terms of social and demographic characteristics. They were selected from rural and urban areas. The children's age is within the range of (7-12) years. The parents' age is within the range of (24-45) years. The children provided a description for family environment. It was found that harsh punishment is the most prevalent family violent behavior. The parents supported the use of physical punishment and the use of power.

Al-Kasab (2011) aimed to explore the reality of family violence against children in the Jordanian society from the perspective of the children themselves. To meet the study's, a questionnaire was developed. This questionnaire consists from 21 items. It was found that the social violence is ranked first, followed by physical violence and psychological violence respectively. It was found that the degree to which respondents suffer from family violence is high. It was found that there are significant differences between the respondents' attitudes which can be attributed to gender. The latter differences are for the favor of females. It was found that there are significant differences between the respondents' attitudes which can be attributed to the father's academic qualification. The latter differences are for the favor of the ones who have BA degree or higher. It was found that there are significant differences between the respondents' attitudes which can be attributed to the place of residence. The latter differences are for the favor of the ones who live in (a village or a camp).

Al-Katebi (2012) aimed to explore the level of family violence against children. He aimed to explore the relationship between family violence against children and experiencing loneliness by those children. The sample consists from 100 female and male $11^{\text {th }}$ grade students in Kafer Batnah and Al-Maleeha in Reef Demashq. The researcher adopted a descriptive analytical approach. He aimed to explore whether there are significant differences between the respondents' attitudes which can be attributed to gender, mother's academic qualification and father's academic qualification. It was found that there is a significant correlation between family violence against children and experiencing loneliness by those children.

Al-Sa'aydeh (2014) aimed to explore the reasons of school violence from the parents' perspective in Era waYarqa in Balqa, Jordan. He conducted the study during the academic year (2010/2011). He aimed to explore the most important methods for fighting against violence. A social survey was used for collecting data. The sample consists from 100 parents; 28 fathers and 72 mothers. It was found that the most important social reasons causing school violence include: 1)-The family's incapability to meet the necessary demands of students. 2)-Being influenced by the colleagues who have bad behaviors. It was found that the most important school reasons causing school violence include: 1)- enforcing strict control over students 2)- having poor administrative leadership in schools. It was found that there isn't any significant difference between the parents' attitudes which can be attributed to gender. However, it was found that there is a significant difference between the parents' attitudes which can be attributed to academic qualification. It was found that the most important methods for fighting against violence include:1)- providing students with a playground and squares. 2)- providing students with counselling services 3)- providing teachers with special training courses about the way of dealing with students in classroom.

Gazwan (2015) aimed to explore the level of family violence against children. He aimed to explore the impacts of such violence on children's personalities. The sample consists from 120 kindergarten children in AlHalah, Babel. It was found that the level of family violence against children is high. It was found that the most prevalent type of family violence against children is verbal violence followed by physical violence and negligence. It was found that the rate of children whose personalities are affected by family violence is low. It was found that there is a significant relationship between the extent of experiencing family violence by child from one hand and the number of family members and the socio-economic status of the family from another hand. It was found that there is a significant relationship between the extent of experiencing family violence by child from one hand and the academic qualifications of the mothers and fathers from another hand.

Assaad, L (2016). This paper explores the methodological challenges of estimating the effects of intimatepartner violence (IPV) against the mother on the educational outcomes of her children. We tackle the problem of potential endogeneity and non-random selection of children into situations where they are exposed to IPV using non-parametric matching methods and parametric instrumental variable methods. Using Colombia's 2005 DHS $(\mathrm{N}=21,827)$ we find that IV and non-IV estimators produce qualitatively similar results, but at varying degrees of precision, for some of the educational outcomes but not for others. This suggests that the exogeneity of IPV to various education outcomes cannot be taken for granted and that appropriate methods need to be used to study its causal effects.

Michele Lloyd's( 2018). This article examines how domestic violence impacts the lives and education of 
young children, children, and young people and how they can be supported within the education system. Schools are often the service in closest and longest contact with a child living with domestic violence; teachers can play a vital role in helping families access welfare services. In the wake of high profile cases of child abuse and neglect, concerns have been raised about the effectiveness of multi-agency responses to children living with abuse. In the United Kingdom, the case of 4-year-old Daniel Pelka who died in 2012 following abuse and starvation by his mother, who experienced domestic violence, and her partner, led to a serious case review. It found recording systems in Daniel's school were not used consistently, and details held by different agencies were not collated to enable the formation of a coherent assessment. The lack of integrated working cited in the report echoes findings from previous serious case reviews. A strong correlation exists between domestic abuse and child abuse, with approximately half of all domestic violence situations involving direct child abuse. Children can also be affected indirectly by violence occurring in their home by seeing or hearing it taking place. This article examines the impact of domestic violence on the mental health of children, and the impact on their education. Violence in children's lives often causes disruption to their schooling and harms the quality of their educational experiences and outcomes. The abuse children experience can result in emotional trauma, physical and psychological barriers to learning, and disruptive behavior in school, while the underlying causes of these problems remain hidden. Knowing when and how to seek advice from multi-agency professionals is an essential part of effective practice among school staff. Despite their vital role in identifying signs of abuse and signposting referral pathways, research indicates teachers often lack confidence and knowledge for such work. The article examines how the professional learning and professional confidence of teachers can be developed, and how recent policy and practice developments in the United Kingdom have the potential to influence work in this area.

Kithonga, S (2018) Exposure to domestic violence among high school learners is one critical issue in schools that needs to be brought at the forefront in understanding dynamics involved and its impact on the learning process. A range of effects not limited to decreased educational performance and behavioural problems arise from domestic violence. Mistakenly, most people fail to see the harm caused to a child living in an abusive household unless physical abuse is extended towards them. Authors of this paper recognize the impact, other than physical, and explore how domestic violence affects the learning process of students in high school. A descriptive design was adopted for the study. With focus in Migwani Sub-county, schools were stratified into two, i.e. girls' and boys' schools. A sample of 56 respondents was then conveniently obtained from 10 public schools. This included students (30), teachers (12), principals (10) and parents (4). Questionnaires and interviews were used to collect data. Data were analysed using the SPSS. The paper presents the perceptions of respondents on domestic violence as the causative agent of sluggishness on learning in Migwani Sub-county. The study is meant to better the learning process in the County.

\section{Differences and similarities between the present study and the aforementioned studies:}

Some of the aforementioned studies shed a light on family violence and its impact on one's personality. Other studies aimed to shed a light on family violence and its relationship with education. For instance, Gazwan (2015) aimed to explore the level of family violence against children. He aimed to explore the impacts of such violence on children's personalities. As for Al-Katebi (2012), he aimed to explore the level of family violence against children. He aimed to explore the relationship between family violence against children and experiencing loneliness by those children. As for Al-Sa'aydeh (2014), he aimed to explore the reasons of school violence from the parents' perspective in Era waYarqa in Balqa, Jordan. As for Al-Sarayrah (2009), he aimed to explore the reasons leading male public secondary school students to committing violent behaviors against teachers and administrators in Jordan. He aimed to explore that from the perspective of students, teachers and administrators. The aforementioned studies- especially the studies of Al-Kassab (2011) and Al-Sa'aydeh (2014) are similar to the present study.

As far as the researchers know, the present study is the first study that aimed to explore the impact of family violence on education and the extent of students' enrollment in public schools in Amman in the light of some variables from the perspective of the special education teachers at these schools. Thus, the subject of the present study makes it distinguhsed from the aforemnetioend studies.

\section{Method and procedures:}

Study methodology: The two researchers used the descriptive survey method for the study.

Study Population: The study population consisted of special education teachers working in public schools within the capital, Amman, and they numbered (4013) male and female teachers, and Table (1) shows the distribution of the study population according to the variables of the study (Ministry of Education, 2019). 
Table (1): Distribution of society according to the study variables

\begin{tabular}{|l|l|l|l|}
\hline Variables & Variable & No. & Total \\
\hline \multirow{4}{*}{ Gender } & Male & $\mathbf{1 7 7 1}$ & \multirow{2}{*}{$\mathbf{4 0 1 3}$} \\
\cline { 2 - 3 } & female & $\mathbf{2 2 4 2}$ & \multirow{3}{*}{$\mathbf{4 0 1 3}$} \\
\hline \multirow{4}{*}{ Experience } & Under 5 years old & $\mathbf{1 0 5 6}$ & \\
\cline { 2 - 3 } & 5-10 years old & $\mathbf{1 2 9 6}$ & \multirow{4}{*}{$\mathbf{4 0 1 3}$} \\
\cline { 2 - 3 } & $10-20$ years & $\mathbf{1 0 2 7}$ & \\
\cline { 2 - 3 } & More than 20 years & $\mathbf{6 3 4}$ & $\mathbf{1 1 5 7}$ \\
\hline
\end{tabular}

The study sample

According to the Stephen Thompson equation, the minimum size of the random stratified sample representing the population was calculated at the significance level $(\alpha \leq 0.05)$, which was (378) male and female teachers, and in anticipation of the waste in the sample in the response, the actual sample size (400) male and female teachers was determined. The researchers divided the capital, Amman, consisting of (7) education directorates. Four districts were chosen as a representative sample of public schools in the capital, Amman, in which they were randomly drawn. The following directorates were chosen within four regions, namely: North Amman, which included the first Amman directorate, the central Amman region, which included the second Amman directorate, West Amman, and included the fifth Amman directorate, and the southern Amman region, and the Giza district, and (378) questionnaires were retrieved from the original (400) questionnaire, where the final sample of the study accounted for $(12 \%)$, and table (2) shows the distribution of the study sample according to the study variables according to the Stephen Thompson equation.

Table (2): Distribution of the sample according to the study variables.

\begin{tabular}{|c|c|c|r|}
\hline Variables & Variable & No. & Total \\
\hline \multirow{3}{*}{ Gender } & Male & $\mathbf{1 1 0}$ & $\mathbf{3 8 2}$ \\
\cline { 2 - 3 } & Female & $\mathbf{2 6 8}$ & $\mathbf{3 8 2}$ \\
& Under 5 years old & $\mathbf{1 9 1}$ & \\
\cline { 2 - 3 } & $5-10$ years old & $\mathbf{8 3}$ & $\mathbf{6 1}$ \\
\cline { 2 - 3 } & $10-20$ years & $\mathbf{4 3}$ & $\mathbf{3 8 2}$ \\
\cline { 2 - 3 } & More than 20 years & $\mathbf{1 5 5}$ & $\mathbf{2 2 3}$ \\
\cline { 2 - 3 } & Diploma & BA & \\
\cline { 2 - 3 }
\end{tabular}

\section{Study Instrument:}

The study instrument was developed by referring to theoretical literature and previous studies such as the Johnson, Brown (2008), Al-Sarayrah (2009), Al-Katibi (2012) and Al-Saaideh (2014) studies, in order to achieve the goals of the study and answer its questions. The primary instrument consisted of (22) paragraphs. It is divided into (3) areas: the physical field, which consists of (7) paragraphs, the psychological field, which consists of (7) paragraphs, and the social field, which consists of (8) paragraphs.

To verify the validity of the study instrument, the study instrument was presented in its initial form to a group of specialized arbitrators, and their number reached (9) from the arbitrators, and they were asked to express an opinion on the paragraphs of the study instrument in terms of drafting the paragraphs, and the degree of their suitability for the field in which they were placed, either with approval or amend their wording, or delete them because they are not important, and their observations were taken regarding amendment, deletion, addition, and merging of paragraphs, until the number of their paragraphs became (22) paragraphs, and an opinion was taken on what was agreed upon by $80 \%$ or more of the arbitrators in the arbitration process.

To verify the stability of the instrument, the internal consistency coefficient was used according to the Cronbach Alpha equation to extract the stability of the study instrument according to the fields, and Table (3) shows the coefficients of the stability of the instrument fields:

Table (3): Stability coefficients of the degree of impact of domestic violence on education and enrollment of students in schools in the capital, Amman, from the point of view of special education teachers

\begin{tabular}{|l|l|l|}
\hline No. & Fields & Cronbach Alpha \\
\hline 1 & Physical field & 0.98 \\
\hline 2 & Psychological field & 0.92 \\
\hline 3 & The social sphere & 0.92 \\
\hline
\end{tabular}


Table (3) shows that the stability coefficients were high, ranging from (0.92 - 0.98$)$.

Study variables

Independent variables:

- Sex has two categories: (female), (male).

- The educational qualification has two categories: (Diploma), (Bachelor degree).

- Experience and has four levels: (less than 5 years), (from 5-10 years), (from 10-20 years), (more than 20 years). The dependent variable: the degree of the effect of family violence on education and the enrollment of students in public schools in the capital, Amman, from the point of view of special education teachers in light of some variables.

Results:

Results related to answering the first question, which states: What is the degree of the impact of domestic violence on education and the enrollment of students in public schools in the capital, Amman, from the point of view of special education teachers?

To answer this question, arithmetic mean, standard deviations, rankings, and degrees were calculated for the effect of family violence on education and students' enrollment in public schools in the capital, Amman, from the point of view of special education teachers, and for each field of study, and Table 4 shows that.

Table (4): Arithmetic mean, standard deviations, rank, and grade for the effect of domestic violence on education and students' enrollment in public schools in the capital, Amman, from the point of view of special education teachers in descending order

\begin{tabular}{|l|l|l|l|l|l|}
\hline No. & Fields & Arithmetic mean & standard deviations & Rank & Degree of availability \\
\hline 3 & Physical field & 3.82 & 0.77 & 1 & High \\
\hline 2 & Psychological field & 3.79 & 0.81 & 2 & High \\
\hline 4 & The social sphere & 3.55 & 0.90 & 3 & Moderate \\
\hline \multicolumn{2}{|l|}{ Overall } & 3.71 & 0.78 & High \\
\hline
\end{tabular}

It is noted in Table (4) that the degree of the effect of domestic violence on education and the enrollment of students in public schools in the capital, Amman, from the point of view of special education teachers came high, as the arithmetic mean (3.71), and the standard deviation (0.78), and the fields came high except for the social field The arithmetic mean ranged between (3.82 - 3.55), and the physical field came first with an arithmetic mean (3.82) and a standard deviation (0.77), and in the second rank the psychological field came with an arithmetic mean (3.79) and a standard deviation (0.81), and in the last rank came the field Social average score (3.55) and standard deviation (0.90).

As for the paragraphs of each field, the results were as follows:

1. Physical field:

Arithmetic averages, standard deviations, ranking, and score for the effect of family violence on education and students' enrollment in public schools in the capital, Amman, were calculated from the point of view of special education teachers for the paragraphs in this field, and Table (5) illustrates this.

Table (5): Arithmetic mean, standard deviations, rank, and grade for the impact of domestic violence on education and students' enrollment in public schools in the capital, Amman, from the viewpoint of special education teachers in the physical field in descending order

\begin{tabular}{|r|l|r|r|r|r|}
\hline No. & Fields & $\begin{array}{l}\text { Arithmetic } \\
\text { mean }\end{array}$ & $\begin{array}{l}\text { standard } \\
\text { deviations }\end{array}$ & Rank & $\begin{array}{l}\text { Degree } \\
\text { availability }\end{array}$ \\
\hline $\mathbf{3}$ & $\begin{array}{l}\text { Physical abuse suffered by a student from one } \\
\text { of his parents is a reason for late school }\end{array}$ & $\mathbf{3 . 9 5}$ & $\mathbf{0 . 9 2}$ & $\mathbf{1}$ & $\mathbf{H i g h}$ \\
$\mathbf{5}$ & $\begin{array}{l}\text { Physical abuse to which the student is exposed } \\
\text { contributes to increasing the level of school } \\
\text { bullying }\end{array}$ & $\mathbf{3 . 9 4}$ & $\mathbf{1 . 0 3}$ & $\mathbf{2}$ & $\mathbf{3 i g h}$ \\
$\mathbf{2}$ & $\begin{array}{l}\text { Beating with a stick by one of the parents } \\
\text { contributes to the emergence of a state of } \\
\text { dullness with the student when he is late to } \\
\text { deliver the assignment }\end{array}$ & $\mathbf{3 . 9 3}$ & $\mathbf{0 . 9 1}$ & $\mathbf{3}$ & $\mathbf{H i g h}$ \\
$\mathbf{4}$ & $\begin{array}{l}\text { Beating and bodily harm is the first method of } \\
\text { punishment that a student is subjected to from } \\
\text { one of his parents when he fails in one of the } \\
\text { subjects }\end{array}$ & $\mathbf{3 . 9 2}$ & $\mathbf{4}$ & $\mathbf{H i g h}$ \\
$\mathbf{1}$ & $\begin{array}{l}\text { Family-oriented students tend to love } \\
\text { controlling their classmates inside the } \\
\text { classroom }\end{array}$ & $\mathbf{3 . 8 7}$ & $\mathbf{0 . 9 4}$ & $\mathbf{5}$ & High \\
\hline
\end{tabular}




\begin{tabular}{|r|l|r|r|r|r|}
\hline No. & Fields & $\begin{array}{l}\text { Arithmetic } \\
\text { mean }\end{array}$ & $\begin{array}{l}\text { standard } \\
\text { deviations }\end{array}$ & Rank & $\begin{array}{l}\text { Degree } \\
\text { availability }\end{array}$ \\
\hline $\mathbf{6}$ & $\begin{array}{l}\text { The student tries to carry a sharp object when } \\
\text { he comes to school to protect himself from any } \\
\text { harm he may be exposed to }\end{array}$ & $\mathbf{3 . 8 1}$ & $\mathbf{0 . 9 5}$ & $\mathbf{6}$ \\
\hline $\mathbf{7}$ & $\begin{array}{l}\text { The sexual assault suffered by the student is a } \\
\text { reason for leaving his studies }\end{array}$ & $\mathbf{3 . 7 4}$ & $\mathbf{0 . 9 7}$ & $\mathbf{7}$ & High \\
\hline \multicolumn{2}{|l|}{ Overall } & $\mathbf{3 . 8 2}$ & $\mathbf{0 . 7 7}$ & High \\
\hline
\end{tabular}

It is noted in Table (5) that the degree of the effect of family violence on education and enrollment of students in public schools in the capital, Amman, from the point of view of special education teachers in the physical field came high, as the arithmetic mean (3.82) and the standard deviation (0.77), and the paragraphs of the field were high As the arithmetic averages ranged between (3.95 - 3.57), and paragraph (3) came in the first rank, which states "Physical abuse to which a student is subjected by one of his parents is considered a reason for delaying school", and in the second rank comes paragraph (5) which It states, "The physical harm to which the student is subject contributes to an increase in the level of bullying." He has, "said paragraph (7), which states," The sexual assault suffered by the student constitutes a reason for leaving his studies. "

2. The psychological field:

Arithmetic mean, standard deviations, grades, and score for the effect of family violence on education and students 'enrollment in public schools in the capital Amman have been calculated from the viewpoint of special education teachers for the paragraphs in this field, and Table (6) illustrates this.

Table (6): Arithmetic mean, Standard Deviations, Ranks, and Degree of Impact of Domestic Violence on Education and Students' Enrollment in Public Schools in the Capital, Amman from the Viewpoint of Special Education Teachers in the Psychological Field Descending

\begin{tabular}{|r|l|r|r|r|r|}
\hline No. & Fields & $\begin{array}{l}\text { Arithmetic } \\
\text { mean }\end{array}$ & $\begin{array}{l}\text { standard } \\
\text { deviations }\end{array}$ & Rank & $\begin{array}{l}\text { Degree } \\
\text { availability }\end{array}$ \\
\hline $\mathbf{2}$ & $\begin{array}{l}\text { Cursing and ridicule contributes to a } \\
\text { weakening of the student's self-confidence and } \\
\text { increases frustration and anxiety }\end{array}$ & $\mathbf{4 . 0 0}$ & $\mathbf{1 . 0 1}$ & $\mathbf{1}$ & High \\
\hline $\mathbf{1}$ & $\begin{array}{l}\text { Parents prevail in the belief that violence } \\
\text { against their children is a method of proper } \\
\text { education }\end{array}$ & $\mathbf{3 . 9 9}$ & $\mathbf{0 . 8 4}$ & $\mathbf{2}$ & High \\
\hline $\mathbf{6}$ & $\begin{array}{l}\text { The marginalization of the student from his } \\
\text { family contributes to weakening the student's } \\
\text { personality and expressing what he has in } \\
\text { mind }\end{array}$ & $\mathbf{3 . 8 1}$ & $\mathbf{1 . 0 2}$ & $\mathbf{3}$ & High \\
\hline $\mathbf{5}$ & $\begin{array}{l}\text { The verbal violence that a student is exposed } \\
\text { to from his parents contributes to poor class } \\
\text { participation }\end{array}$ & $\mathbf{3 . 7 5}$ & $\mathbf{0 . 9 8}$ & $\mathbf{4}$ & High \\
\hline $\mathbf{4}$ & $\begin{array}{l}\text { The contempt for the student from his family } \\
\text { leaves the school }\end{array}$ & $\mathbf{3 . 7 4}$ & $\mathbf{1 . 0 1}$ & $\mathbf{5}$ & High \\
\hline $\mathbf{7}$ & $\begin{array}{l}\text { Student employment with his father late at } \\
\text { night is a reason for his low level of education }\end{array}$ & $\mathbf{3 . 7 1}$ & $\mathbf{1 . 0 0}$ & $\mathbf{6}$ & High \\
\hline $\mathbf{3}$ & $\begin{array}{l}\text { The student feels panic and fear when } \\
\text { criticizing him from the teacher as a result of } \\
\text { the level of domestic violence he is exposed to }\end{array}$ & $\mathbf{3 . 6 3}$ & $\mathbf{1 . 0 9}$ & $\mathbf{8}$ & Moderate \\
\hline
\end{tabular}

It is noted in Table (6) that the degree of the effect of domestic violence on education and the enrollment of students in public schools in the capital Amman / Brigade of the Kasbah during the period 2009-2019 from the point of view of teachers in the psychological field came high as the arithmetic mean (3.79), and the standard deviation (0.81), And all the paragraphs of this field came out high, as the arithmetic mean of the paragraphs ranged between (4.00 - 3.63) and came in the first rank, paragraph (2), which states "cursing and ridicule contributes to weakening the student's confidence in himself and increases his feeling of frustration and anxiety", and in the second rank came Paragraph (1) which states, "Fathers prevail over the belief that violence against children is prevalent They are a means of proper education. "Paragraph (3) states that" the student feels panic and fear when directing any criticism from the teacher as a result of the level of domestic violence to which he is exposed."

3. The social sphere:

Arithmetic mean, standard deviations, grades, and grade were calculated for the effect of family violence on 
education and the enrollment of students in public schools in the capital Amman from the viewpoint of special education teachers for the paragraphs in this field, and Table (7) illustrates this.

Table (7): Arithmetic mean, standard deviations, grades and grade for the effect of domestic violence on education and the enrollment of students in public schools in the capital, Amman, from the viewpoint of special education teachers in the social field, arranged in descending order

\begin{tabular}{|r|l|r|r|r|r|}
\hline No. & Fields & $\begin{array}{l}\text { Arithmetic } \\
\text { mean }\end{array}$ & $\begin{array}{l}\text { standard } \\
\text { deviations }\end{array}$ & Rank & $\begin{array}{l}\text { Degree } \\
\text { availability }\end{array}$ \\
\hline $\mathbf{1}$ & $\begin{array}{l}\text { Conflict and family divorce cases contribute to the } \\
\text { student not coming to school }\end{array}$ & $\mathbf{3 . 6 3}$ & $\mathbf{1 . 1 0}$ & $\mathbf{1}$ & Moderate \\
\hline $\mathbf{6}$ & $\begin{array}{l}\text { Domestic violence affected the student's ability to } \\
\text { communicate and interact with his schoolmates }\end{array}$ & $\mathbf{3 . 6 0}$ & $\mathbf{1 . 0 6}$ & $\mathbf{2}$ & Moderate \\
\hline $\mathbf{7}$ & $\begin{array}{l}\text { A family-sanctioned student suffers from poor class } \\
\text { participation }\end{array}$ & $\mathbf{3 . 6 0}$ & $\mathbf{1 . 0 6}$ & $\mathbf{2}$ & Moderate \\
\hline $\mathbf{4}$ & $\begin{array}{l}\text { A family-sanctioned student suffers from poor } \\
\text { participation in school broadcasting }\end{array}$ & $\mathbf{3 . 5 7}$ & $\mathbf{1 . 1 0}$ & $\mathbf{4}$ & Moderate \\
\hline $\mathbf{8}$ & $\begin{array}{l}\text { A family-bombed student tries to go to sleep in the } \\
\text { classroom as a way to forget about the family } \\
\text { problems he is going through }\end{array}$ & $\mathbf{3 . 5 4}$ & $\mathbf{1 . 0 5}$ & $\mathbf{5}$ & Moderate \\
\hline $\mathbf{5}$ & $\begin{array}{l}\text { The cultural gap between the family-battered student } \\
\text { and his colleagues inside the classroom increases due } \\
\text { to the domestic violence that he is exposed to. }\end{array}$ & $\mathbf{3 . 5 2}$ & $\mathbf{1 . 0 9}$ & $\mathbf{6}$ & Moderate \\
\hline $\mathbf{2}$ & $\begin{array}{l}\text { A family-sanctioned student needs to review the } \\
\text { resource room in order to identify social problems } \\
\text { and try to address them }\end{array}$ & $\mathbf{3 . 5 1}$ & $\mathbf{1 . 0 9}$ & $\mathbf{7}$ & Moderate \\
\hline $\mathbf{3}$ & $\begin{array}{l}\text { A family-bombed student cannot fully integrate with } \\
\text { teachers and school subjects }\end{array}$ & $\mathbf{3 . 4 9}$ & $\mathbf{1 . 0 4}$ & $\mathbf{8}$ & Moderate \\
\hline
\end{tabular}

It is noted in Table (7) that the degree of the effect of family violence on education and enrollment of students in public schools in the capital, Amman, from the point of view of special education teachers in the social field came average, as the arithmetic mean (3.55) and the standard deviation (0.90), and the paragraphs of the field were moderate As the arithmetic mean ranged between (3.63 - 3.49), and paragraph 1 (1) stipulated that "cases of conflict and family divorce contribute to the student not coming to school," and in the second level, paragraph (6) which states "for domestic violence" It affected the student's poor ability to communicate and interact with his schoolmates,

Results related to answering the second question, which states: Are there statistically significant differences at the level of significance $(\alpha \leq 0.05)$ of the responses of the members of the study community towards the degree of the effect of domestic violence on education and the enrollment of students in public schools in the capital Amman due to the gender variable?

To answer this question, arithmetic mean and standard deviations were calculated for the degree of the effect of family violence on education, enrollment of students in public schools in the capital, Amman, and a t-test according to the gender variable, and Table (8) shows that.

Table (8): Arithmetic mean, standard deviations for the degree of the effect of family violence on education and students 'enrollment in public schools in the capital, Amman, from the viewpoint of special education teachers and a t-test according to the gender variable

\begin{tabular}{|c|c|c|c|c|c|c|}
\hline Fields & Gender & No. & Arithmetic mean & Standard deviation & T value & Sig \\
\hline \multirow[t]{3}{*}{ Physical field } & female & 270 & 3.86 & 0.77 & \multirow[t]{2}{*}{2.74} & \multirow[t]{2}{*}{0.00} \\
\hline & Male & 112 & 3.61 & 0.86 & & \\
\hline & Overall & 382 & 3.73 & 0.81 & & \\
\hline \multirow[t]{3}{*}{ Psychological field } & female & 270 & 3.85 & 0.75 & \multirow[t]{2}{*}{1.14} & \multirow[t]{2}{*}{0.25} \\
\hline & Male & 112 & 3.75 & 0.81 & & \\
\hline & Overall & 382 & 3.80 & 0.78 & & \\
\hline \multirow[t]{3}{*}{ The social sphere } & female & 270 & 3.58 & 0.92 & \multirow[t]{2}{*}{0.89} & \multirow[t]{2}{*}{0.37} \\
\hline & Male & 112 & 3.49 & 0.91 & & \\
\hline & Overall & 382 & 3.53 & 0.91 & & \\
\hline \multirow[t]{3}{*}{ Total marks } & female & 270 & 3.63 & 0.82 & \multirow[t]{2}{*}{2.55} & \multirow[t]{2}{*}{0.01} \\
\hline & Male & 112 & 3.43 & 0.83 & & \\
\hline & Overall & 382 & 3.53 & 1.65 & & \\
\hline
\end{tabular}


It is noted from Table (8) that there are apparent differences between the arithmetic mean of the degree of the effect of family violence on education and the enrollment of students in public schools in the capital, Amman, from the point of view of special education teachers according to the gender variable, as females got the highest arithmetic mean of (3.63) compared to males, as The average calculation for this category was (3.53), and to determine whether the differences between the means are statistically significant at the level of significance $(\alpha \leq$ 0.05) t-test was applied, as the results in Table (8) indicate the presence of statistically significant differences at the level of The significance $(\alpha \leq 0.05)$ of the degree of the effect of domestic violence on education and the enrollment of students in school For a government woman in the capital Amman / brigade from the teachers 'point of view according to the gender variable based on the calculated value of $(\mathrm{T})$, as it reached (2.55) and the level of significance (0.01) for the total degree, and also in the psychological field, as the difference was in favor of females in the evidence of their high arithmetic mean, Also, there were no statistically significant differences for the (physical and social) domains.

Results related to answering the third question, which states: Are there statistically significant differences at the level of significance $(\alpha \leq 0.05)$ of the responses of the members of the study community towards the degree of the impact of family violence on education and the enrollment of students in public schools in the capital Amman due to the variable of educational qualification?

To answer this question, arithmetic mean and standard deviations were calculated for the degree of the effect of family violence on education, enrollment of students in public schools in the capital, Amman, and (t-test) according to the variable of the educational qualification, and Table (9) shows that.

Table (9): Arithmetic mean, standard deviations, the degree of the impact of family violence on education, students 'enrollment in public schools in the capital, Amman, from the point of view of special education teachers, and (t-test) according to the variable of the educational qualification

\begin{tabular}{|c|c|c|c|c|c|c|}
\hline Fields & Gender & No. & Arithmetic mean & Standard deviation & T value & Sig \\
\hline \multirow[t]{3}{*}{ Psychological field } & diploma & 157 & 3.73 & 0.77 & \multirow[t]{2}{*}{-1.77} & \multirow[t]{2}{*}{0.07} \\
\hline & BA & 225 & 3.88 & 0.86 & & \\
\hline & Overall & 382 & 3.80 & 0.81 & & \\
\hline \multirow{3}{*}{ Physical field } & diploma & 157 & 3.77 & 0.75 & \multirow[t]{2}{*}{-1.49} & \multirow[t]{2}{*}{0.13} \\
\hline & $\mathrm{BA}$ & 225 & 3.89 & 0.81 & & \\
\hline & Overall & 382 & 3.83 & 0.78 & & \\
\hline \multirow{3}{*}{ The social sphere } & diploma & 157 & 3.46 & 0.92 & \multirow[t]{2}{*}{-2.43} & \multirow[t]{2}{*}{0.01} \\
\hline & $\mathrm{BA}$ & 225 & 3.69 & 0.91 & & \\
\hline & Overall & 382 & 3.57 & 0.91 & & \\
\hline \multirow[t]{3}{*}{ Total marks } & diploma & 157 & 3.53 & 1.64 & \multirow[t]{2}{*}{-1.28} & \multirow[t]{2}{*}{0.20} \\
\hline & BA & 225 & 3.63 & 1.67 & & \\
\hline & Overall & 382 & 3.58 & 1.65 & & \\
\hline
\end{tabular}

It is noted from Table (9) that there are apparent differences between the arithmetic mean of the degree of the effect of family violence in education and the enrollment of students in public schools in the capital, Amman, from the point of view of special education teachers according to the variable of the educational qualification, as teachers with a bachelor's degree obtained the highest arithmetic average of (3.63). (Compared to teachers who hold a diploma degree, the mean arithmetic for this class reached (3.58), and to determine whether the differences between the arithmetic mean are statistically significant at the level of significance $(\alpha \leq 0.05)$ test $(\mathrm{t})$ was applied, as the results indicate in the table (9) The absence of statistically significant differences at M. The significance level $(\alpha \leq 0.05)$ for the degree of the effect of family violence in education and the enrollment of students in public schools in the capital Amman from the point of view of special education teachers according to the variable of the educational qualification, based on the calculated value of $(\mathrm{T})$, as it reached $(-1.28)$, and the level of significance ( 0.20$)$ for the total degree, and it was found that there were no statistically significant differences in all fields except the social field.

Results related to answering the fourth question, which states: Are there statistically significant differences at the level of significance $(\alpha \leq 0.05)$ of the responses of the members of the study community towards the degree of the effect of domestic violence on education and the enrollment of students in public schools in the capital Amman due to the variable of experience?

To answer this question, arithmetic mean and standard deviations were calculated for the degree of the effect of family violence on education, enrollment of students in public schools in the capital, Amman, and a t-test according to the variable of the educational qualification. Table 10 shows that. 
Table (10): Arithmetic mean, standard deviations, the degree of the impact of family violence on education, students 'enrollment in public schools in the capital, Amman, from the point of view of special education teachers, and (t-test) according to the variable of experience

\begin{tabular}{|c|c|c|c|c|}
\hline Field & Academic Rank & No. & Arithmetic mean & Standard Deviation \\
\hline \multirow{5}{*}{$\begin{array}{l}\text { Psychological } \\
\text { field }\end{array}$} & Less than 5 years & 192 & 3.81 & 0.60 \\
\hline & From 5-10 years & 84 & 3.90 & 0.89 \\
\hline & $10-20$ years old & 62 & 3.77 & 0.81 \\
\hline & More than 20 years & 44 & 3.67 & 0.80 \\
\hline & Overall & 382 & 3.78 & 0.77 \\
\hline \multirow{5}{*}{ Physical field } & Less than 5 years & 192 & 3.88 & 0.62 \\
\hline & From 5-10 years & 84 & 3.83 & 0.83 \\
\hline & 10-20 years old & 62 & 3.82 & 0.76 \\
\hline & More than 20 years & 44 & 3.77 & 0.81 \\
\hline & Overall & 382 & 3.82 & 0.75 \\
\hline \multirow{5}{*}{$\begin{array}{l}\text { The social } \\
\text { sphere }\end{array}$} & Less than 5 years & 192 & 3.56 & 0.88 \\
\hline & From $5-10$ years & 84 & 3.69 & 0.92 \\
\hline & $10-20$ years old & 62 & 3.49 & 0.91 \\
\hline & More than 20 years & 44 & 3.57 & 0.96 \\
\hline & Overall & 382 & 3.75 & 0.91 \\
\hline \multirow[t]{5}{*}{ Total marks } & Less than 5 years & 192 & 3.61 & 1.59 \\
\hline & From $5-10$ years & 84 & 3.69 & 1.73 \\
\hline & 10-20 years old & 62 & 3.54 & 1.61 \\
\hline & More than 20 years & 44 & 3.45 & 0.84 \\
\hline & Overall & 382 & 3.57 & 1.44 \\
\hline
\end{tabular}

It is noted from Table (10) that there are apparent differences between the arithmetic mean of the degree of the effect of family violence on education and the enrollment of students in public schools in the capital Amman from the viewpoint of teachers of special education, according to the variable of experience, as those who have experience (5-10 years) got the highest average My arithmetic reached (3.69), and those with experience (less than 5 years) came in the second rank, as the arithmetic average reached (3.61), and in the last rank came those who have experience (more than 20 years), when the arithmetic average (3.46). To determine whether the differences between the averages were statistically significant at the level of significance $(\alpha \leq 0.05)$, one way ANOVA was applied, and the results of the analysis of variance came as shown in Table (11):

\begin{tabular}{|c|c|c|c|c|c|c|}
\hline Fields & $\begin{array}{l}\text { Source of } \\
\text { contrast }\end{array}$ & $\begin{array}{l}\text { Sum of } \\
\text { squares }\end{array}$ & $\begin{array}{l}\text { Degrees } \\
\text { freedom }\end{array}$ & $\begin{array}{l}\text { Average } \\
\text { squares }\end{array}$ & $\begin{array}{l}\mathbf{F} \\
\text { value }\end{array}$ & Sig \\
\hline \multirow{3}{*}{$\begin{array}{l}\text { Psychological } \\
\text { field }\end{array}$} & Between groups & 1.982 & 3 & 0.661 & 1.00 & 0.39 \\
\hline & Within groups & 305.594 & 379 & 0.572 & & \\
\hline & Total & 307.576 & 382 & & & \\
\hline \multirow{3}{*}{ Physical field } & Between groups & 0.275 & 3 & 0.092 & 0.15 & 0.92 \\
\hline & Within groups & 193.612 & 379 & 0.876 & & \\
\hline & Total & 193.887 & 382 & & & \\
\hline \multirow{3}{*}{ The social sphere } & Between groups & 2.295 & 3 & 0.765 & 0.90 & 0.43 \\
\hline & Within groups & 290.198 & 379 & 0.831 & & \\
\hline & Total & 292.493 & 382 & & & \\
\hline \multirow[t]{3}{*}{ Total marks } & Between groups & 3.076 & 3 & 0.316 & 0.63 & 0.56 \\
\hline & Within groups & 295.151 & 379 & 0.311 & & \\
\hline & Total & & 382 & & & \\
\hline
\end{tabular}

The results in Table (11) indicate that there are no statistically significant differences at the level of significance $(\alpha \leq 0.05)$ of the degree of the effect of family violence in education and the enrollment of students in public schools in the capital Amman from the point of view of special education teachers according to the variable of experience for the total degree, based on the value of $(\mathrm{P})$ calculated, as it reached $(0.63)$, and at the level of significance (0.56), and it was found that there were no statistically significant differences in all fields.

\section{Discuss the study results:}

First: Discussing the results related to answering the first question, which stipulated: What is the degree of the impact of family violence on education and the enrollment of students in government schools in the capital Amman / brigade in the Kasbah during the period 2009-2019 from the viewpoint of teachers?

The results showed that the degree of the effect of family violence on education and the enrollment of students 
in government schools in the capital Amman / Liwa al-Kasaba during the period 2009-2019 from the teachers point of view came high, which indicates the need to study family violence and the degree of its impact on education and students' enrollment in schools and work to develop Effective solutions that reduce the impact of this impact in order to improve the level of students in terms of education and ensure the provision of better educational opportunities for them and achieve the principle of distributive justice and achieve equal educational opportunities for all. The "physical" field came in the first rank with a high degree, and this may be due to the weakness of deterrence factors represented in the activation of laws and regulations that were put in place to protect the regular individual on school seats in government schools in addition to the weak awareness of the family of the danger of physical humiliation and what has a negative impact on the student's attendance at his school And on his academic achievement, and this result is consistent with the study (Ghazwan, 2015), and the study (AlSaaideh, 2014), and the study (Al-Kasab, 2011). As for the second rank, the psychological field came, with a high degree, and this may be due to the seriousness of domestic violence in all its forms. The student's psyche and his ability to communicate Ali with the teachers and with his colleagues in the classroom, especially visual communication when speaking in expressing what he has in mind, and the psychological aspect plays a large role in increasing the failure rates, school dropout and absence from the classes, which is reflected at the educational level of the student and contributes to increasing the illiteracy rate, as well The psychological aspect of domestic violence plays in increasing the student's school bullying, which may lead to his dismissal from school and his denial of education, especially if that bullying turns into a crime in which the battered student may fall into with one of his colleagues or his teachers, and this result is consistent with a study (Assaad, 2016) The study of writer (2012) The Johnson and Brown study (2008). As for the third rank, the social field came, but to a moderate degree. This may be attributed to the impact of the major family violence in isolating the student from the school environment and his activities and his role in weakening the student's personality and creating from him a lazy person and not optimistic and not accepting the other and discontented The community and such an issue requires the intervention of the school by activating more meetings with parents in order to reach a state of agreement about separating the student from the circle of family problems, especially those that occur between parents, in addition to identifying the nature of the family violence features to which the student is exposed in terms of the meeting Of which it is reflected by the negative turnout on the school and exercise its right would education like the rest of the students attending the school, and agree this result with a study (Ghazwan, 2015), study al-Kassab (2011), study (2010Michele lioyds,).

With regard to the areas of the degree of the impact of domestic violence on education and the enrollment of students in government schools in the capital, Amman / Liwa al-Kasaba during the period 2009-2019 from the teachers point of view, its results were discussed as follows:

\section{Physical field}

The results showed that the degree of the impact of domestic violence on education and enrollment of students in government schools in the capital Amman / Brigade of the Kasbah during the period 2009-2019 from the point of view of teachers in the physical field was high, and this result is consistent with the study (Ghazwan, 2015), and the study (Al-Sa'idah, 2014 ), And a study (Al-Kasab, 2011) came in the first rank, paragraph (3), which states "Physical abuse to which a student is subjected by one of his parents is considered a reason for delaying school", and this may be due to the student's exposure to physical abuse that may have a knot Psychological in front of his peers in the same classroom, especially if there were signs of beating or slapping on his face or One of his limbs, which cannot be concealed as the fingers of a hand, as this would be a reason for his being ridiculed by his fellow students, so the student resorted to delaying school or absenteeism on that day, as mentioned in the second rank in paragraph (5), which states "Physical abuse to which the student is exposed To increase the level of school bullying he has. "This may be attributed to the entrenchment of the culture of violence among the abused student and work to imitate the manifestations of violence he is exposed to in the vicinity of his family and transfer them to the vicinity of his school. Paragraph (2) came in the third rank which states" Beating with a stick by One of the parents in the emergence of a state of dullness for the student at the delay Its delivery due course "may be due to a number of old societal norms and traditions and convinced the parents of the impact of the use of the stick on the student if they fail or delay to catch up with the level of knowledge of his colleagues in arguing grade so that the stick of paradise. And it came in the fourth rank of paragraph (4), which states, "Beating and physical abuse is the first means of punishment that a student is subjected to from one of his parents when he fails in one of the subjects." This may be attributed to the parents 'conviction that beating and physical abuse is the shortest way to obtain educationally beneficial results, And it came in the fifth rank, paragraph (1), which states, "The family-battered student tends to love controlling his colleagues inside the classroom." This may be due to the family-battered student's desire to relieve the anger and suppression that he suffers in his family, as stated in the sixth rank, paragraph (6). ) Which states "The student tries to carry a sharp object when idle He went to school to protect himself from abuse that he might be exposed to. "This may be due to the anxiety felt by the family-abused student and his need for protection. As for the last rank, paragraph (7) states that" the sexual assault suffered by the student is a reason for leaving His study "This may be attributed to the broken hopes of the family-battered student for the 
continuity of the healthy life that he hopes to lead, especially among females.

\section{The psychological field}

The results showed that the degree of the impact of family violence on education and enrollment of students in government schools in the capital Amman / Brigade of the Kasbah during the period 2009-2019 from the point of view of teachers in the psychological field came high, and this result is consistent with the study (Assaad, 2016), and the study of writer (2012), And Johnson and Brown (2008) study came in the first rank in paragraph (2), which states "cursing and ridicule contributes to weakening the student's self-confidence and increases his feeling of frustration and anxiety." The researcher attributes this to the fact that the student lives during his studies in adolescence, which is characterized by The student's personality is in a state of weakness and wasting in terms of the degree of high level of sensitivity Any negative behavior, practice, or behavior that a non-violent student may be exposed to, so how can a violent student who suffers from anxiety and frustration acquired by the family to which he belongs, and came in the second rank in paragraph (1) which states "Parents prevail in the belief that the practice of violence against their children is a means One of the right means of education "may be attributed to the norms and beliefs that prevail in the Arab community, which lived and still lives in a state of violence, turmoil and lack of acceptance of the other, as stated in the third rank, paragraph (6), which states" The marginalization which the student from his family contributes to Weakening the personality of the student and expressing his thoughts "and he may return This is due to the student's great need to communicate and listen to him and not to suppress him by various means because the student's personality is a set of internal needs that make him tend to respond to the things surrounding him in a special way, and it came in the fourth rank of paragraph (5) which states, "Verbal violence that The student is exposed to it by his parents in weak class participation. "This may be attributed to the shaking of the student's self-confidence and his conviction of his inability to express correctly due to the wave of frustration he is exposed to resulting from the accusations he faces from his family, which is the result of his unintended behavior or his failure to do something, It came in For the fifth rank of paragraph (4) which states, "The contempt to which the student from his family is exposed to drop out from school." This may be due to the student's weak ability to continue in school education and to carry out the burdens of his ongoing duty so he resort to school dropout and does not complete his daily career in school and that As an inevitable result of the weakness of the family's conviction of its capabilities and abilities to keep up with its peers in school with regard to excellence in school duties and good disposition in daily preparation and active class participation, came in the sixth rank of paragraph (7) which states "The student's employment with his father is late hours of The reason for the low level of study "This may be due to the high degree of fatigue and fatigue to which the student is subjected, which reflects negatively on his academic level in terms of preparation and completion of daily duties, class participation and academic achievement. As for the last rank, paragraph (3) states that on "the student feels panic and fear when directing any criticism from him from the teacher as a result of the level of domestic violence to which he is exposed." This may be due to the student's fear of what he might receive from his parents or one of them if the news of his failure or his achievement level falls to his family, especially if Parents belonged to a group Societal beliefs that beatings are seen as a key way to ensure student success in education.

\section{The social sphere}

The results showed that the degree of the impact of family violence on education and the enrollment of students in government schools in the capital Amman / Liwa al-Kasaba during the period 2009-2019 from the point of view of teachers in the social field came medium, and this result is consistent with the study (Ghazwan, 2015), and the study of Kasab (2011) And a study (2010 Michele lioyds), and came in the first rank paragraph (1) which states "conflict and family divorce cases contribute to the student not coming to school", and this may be due to the student feeling psychological insecurity as a result of that divorce so the student will resort to the place he believes It provides him with the security he lost, which does not include accountability or follow-up The grandfather of a student who comes from a family suffering from a conflict or divorce is discharged in the streets and between alleys, and came in second rank, paragraph (6), which states "family violence affects the weak ability of the student to communicate and interact with his schoolmates" and this may be due to personal weakness The student and his inability to exchange information and ideas with others, especially if he is subjected to a state of muzzling in his family and not being allowed to express his opinion, as stated in the second rank paragraph (7), which states that "a family-bombed student suffers from a lack of class participation" This is due to the battered student's inability to receive any direction or We criticize his mentor or colleagues in the classroom if he erred in the information he provided, as a result of his poor visual or verbal communication with others. It came in the fourth rank, paragraph (4), which states that "a family-assaulted student suffers from a weak participation in school broadcasting" and may return This is due to the weakness of his ability to confront students and make his voice heard for them, but in the fifth rank came paragraph (8) which states, "The family-abused student tries to go to sleep in the classroom as a way to forget the family problems he is going through" and this may be due to the need of the abused student To escape from the reality of the violence taking place in a family At the same time to ensure that it does not occur in embarrassment when opening the way to talk about his family reality in which he lives. As for the sixth rank, paragraph (5) came, which states, "The cultural gap between the family-battered student and 
his colleagues within the classroom increases," and this may be due to Student delinquency in absence and school dropout and spending time scheduled to study outside the walls of the school, which leads to a cultural gap between the abused student and the rest of the students due to the lost educational lessons and class and extra-curricular activities that contribute to building his intellectual system, and came in the seventh grade paragraph (2) which It states "Needs A student who is family-battered to review the resource room in order to identify social problems and try to address them. This may be due to the conviction of the school administration of the importance of the resource room, which includes the psychological specialist who is able to come to terms with what comes to mind in the psychology of the battered student and try to translate it to school management so that it can develop strategies that contribute to Treating that group of battered students family, but in the last rank came paragraph (3), which states, "A family-battered student cannot fully integrate with teachers and school subjects." This may be due to the battered student's conviction that isolation from School environment is a solution to help him overcome the problems faced by them.

Second: Discussing the results related to answering the second question, which states: Are there statistically significant differences at the level of significance $(\alpha \leq 0.05)$ for the responses of the members of the study community towards the degree of the impact of family violence on education and the enrollment of students in government schools in the capital, Amman / Liwa al-Kasaba during the period 2009 -2019 due to the gender variable?

The results showed that there are statistically significant differences at the level of significance $(\alpha \leq 0.05)$ of the degree of the effect of domestic violence on education and the enrollment of students in government schools in the capital Amman / brigade of the Kasbah during the period 2009-2019 from the teachers point of view, according to the gender variable for the total degree, where the differences came In favor of the female category in the fields (physical, psychological, and social) as evidence of their high arithmetic averages when compared with the male category in the overall degree, this may be due to the ability of females - female teachers - to take note of the nature of the physical, psychological and social problems experienced by female students who are family abused by virtue of the ruling The blood of the student's ability to be absent or drop out of school due to the societal norms and traditions that govern the necessity of the female staying either at home or at school, in addition to the fact that females are able to withdraw speech from female students 'mouths by virtue of the female nature which is overpowered by emotion which leads to fluency in expressing what comes to mind And talking about all the family problems she suffers, as the female - female teachers - are better able to discover a student who is self-defeating or suffers from frustration, as a result of her distinction with her delicate sense and reading facial expressions that appear more clearly on female students than male students, and the results of the Dur Study with current results Ghazwan (2015 study), study Alcassap (2011.(

Third. Discuss the results related to answering the third question, which states: Are there statistically significant differences at the level of significance $(\alpha \leq 0.05)$ of the responses of the members of the study community towards the degree of the impact of family violence on the enrollment of students in government schools in the capital Amman / brigade brigade during the period 2009-2019 attributed For the variable of qualification?

The results showed that there were no statistically significant differences at the level of significance $(\alpha \leq 0.05)$ of the degree of the effect of family violence on the enrollment of students in government schools in the capital Amman / District of the Kasbah during the period 2009-2019 due to the variable of the academic qualification for the total degree, and this result is clearly demonstrated in the category Bachelor's degree in evidence of their high arithmetic averages in the areas (physical, psychological, and social), and the researcher attributes this to teachers 'interest in teaching and preparation issues, taking exams, and documenting marks more at the expense of interest in what is related to the student from family matters where they see that discussing such matters is from Pat the school administration and psychological counselor agree the results of the current study in all fields with a study (Alkateba 2012.(

Fourthly. Discuss the results related to answering the third question, which states: Are there statistically significant differences at the level of significance $(\alpha \leq 0.05)$ of the responses of the members of the study community towards the degree of the impact of family violence on the enrollment of students in government schools in the capital Amman / brigade during the period 2009-2019 attributed For an experience variable?

The results showed that there were no statistically significant differences at the level of significance $(\alpha \leq 0.05)$ of the degree of the effect of domestic violence on the enrollment of students in government schools in the capital Amman / Brigade of the Kasbah during the period 2009-2019 due to the variable of experience of the total degree, and this may be due to the fact that domestic violence The student is exposed to it. The battered student's colleagues in the classroom may be able to deal with him and reveal that the process of correcting the battered student's behavior may be carried out by the parent of any student or junior teacher, no matter how small his experience is, or how large or large the results of the current study in all its fields are with the Al-Saaideh study (2014) And study (Kithonga, 2018). 
Recommendations:

The researchers of the present study recommend:

1) Adopting special mechanisms by the Ministry of Education for dealing with the students who suffer from family violence. For instance, special education must be provided to them. Counselors must provide support to those students.

2) Academic leaders must provide attention to family violence against students. For instance, it must encourage researchers to conduct studies in a periodical manner about such violence. Such studies must explore the conditions and problems of those families.

3) Activating the role of parents councils in fighting against family violence.

\section{References}

Ghazwan, Anas (2015). Domestic violence against children and its reflection on the personality, Journal of Babylon University, 23 (4), 2155-2175.

Al-Kasab, Ali (2011) The reality of family violence against children in Jordanian society from the perspective of the children themselves, Journal of Arab Childhood, 5 (64), 33-64.

Al-Katbi, Muhammad (2012), Domestic violence directed towards children and its relationship to psychological unity, Journal of Damascus University, 28 (1), 67-107.

Hayat, Daas (2010) A field study to uncover child victims of violence, methods and parties involved in it, unpublished Master Thesis, University of Mentouri Constantine, Algeria.

Al-Saaideh, Jihad (2014) Causes of School Violence and Means of Reducing it from the Point of View of Parents of Higher Basic Stage Students in Jordan, Journal of Dirasat, 41 (1), 54-69.

Al-Sarayrah, Khaled (2009). Reasons for student violence behavior directed against teachers and administrators in government secondary schools in Jordan from the viewpoint of students, teachers, and administrators, Jordanian Journal of Educational Sciences, 5 (2), 137-157.

Al-Baher, Ibrahim (2015). Dictionary of Educational Administration Concepts and Vocabulary, Amman: Dar Al-Amreya.

Abu Ghazaleh, Haifa (2008), Domestic Violence in Jordan (Knowledge, Trends, and Reality), National Council for Family Affairs.

Bushnaq, Nadia and others (2014). A guide for dealing with family violence, Zarqa: Family Awareness and Guidance Center.

Al-Fawaz, Abdel-Rahman (2008). An Exploratory Study of Domestic Violence Toward Women and Children in Jordan, Journal of Culture and Development, 1 (28), 190-228.

Al-Taweel, Hani (2019). The Educated School, Amman: Dar Wael for Publishing.

Taraby, Mamoun (2012). Concepts of family, family and kinship, Beirut: Dar Al-Neama Al-Arabia.

Abdel-Gawad, Hani and Al-Batayneh, Muhammad (2004): Characteristics of victims and perpetrators of domestic violence in Jordan, The Higher Council for Science and Technology, Amman, Jordan.

Bahri, Mona Younis (2011) Domestic Violence, Amman: Dar Al-Safa for Publishing and Distribution.

Hussain, Ali (2017). Domestic Violence against Children and its Impact on Academic Achievement, Unpublished Master Thesis, University of Qadisiyah, Iraq.

Lloyd's, Michele ( 2018). Domestic Violence and Education: Examining the Impact of Domestic Violence on Young Children, Children, and Young People and the Potential Role of Schools, international journal of education policy research and review, 2(4),47-51.

Kithonga's, F (2018). The Impact of Domestic Violence on The Learning Process of High School Students, unpublished master, st, johns university, new York.

Assaad, R (2016). Impact of Domestic Violence on Children's Education in Colombia: Methodological Challenges, International Journal of Humanities and Social Science, 4(3),25-36.

Janson, s \& Brown, j (2008). Childrearing and child participation in Jamaican families journal articles, international journal of early years education, 16(1), 31-40 .

Lampie, G (2008). Child abuse and neglect: a practical guide for professional school counselors, professional school counselors, 8(3), 175-193 .

Fredric,L \& Fredjr,A (2010). Intensive family based services program, preventing and improving mechanism in children abused and neglected through PCTT, self management skills, and intensive child play counseling edd, Nova, South western University. 